\title{
Investigation of the properties of $\mathrm{Cr}$ coatings deposited in an improved $\mathrm{Cr}$ (III) electrolyte
}

Gedvidas Bikulčius,

Asta Češūnienè $\dot{x}^{*}$

Tadas Matijošius,

Aušra Selskienè,

Vidas Pakštas

Institute of Chemistry,

CPST (Center for Physical Sciences

and Technology),

3 Sauletekio Avenue,

10222 Vilnius, Lithuania
In this study, mechanical and tribological properties of $\mathrm{Cr}$ coatings obtained from a $\mathrm{Cr}$ (III) sulfate bath with addition of the heterocyclic compound (HCC) prepared on mild steel have been investigated. The chromium plating electrolyte containing the HCC additive enables us to deposit the $\mathrm{Cr}$ coatings at low $\left(20^{\circ} \mathrm{C}\right)$ temperature and low current densities. Small amounts (from 20 to $60 \mathrm{mgl}^{-1}$ ) of HCC were added to the $\mathrm{Cr}(\mathrm{III})$ sulfate bath in order to study the effects of HCC on coating formation. At an optimal concentration of $40 \mathrm{mgl}^{-1}$, the HCC additive to the solution ensures a high surface microhardness of the $\mathrm{Cr}$ deposits obtained $\left(\mathrm{HV}_{0.05}=1036 \mathrm{~kg} \mathrm{~mm}^{-2}\right)$ without a subsequent heat treatment. The dry sliding wear tests have shown that the $\mathrm{Cr}$ coatings have both a low friction coefficient and a low wear rate. The $\mathrm{Cr}$ (III) bath with the HCC additive is more eco-friendly and requires less energy compared with a conventional $\mathrm{Cr}(\mathrm{III})$ process.

Keywords: trivalent chromium, hardness, XRD, friction coefficient, wear rate

\section{INTRODUCTION}

According to EU Regulation (EC) No. 1907/2006 ('REACH') the use of chromium trioxide baths for functional and decorative chromium plating has been limited since 1 September 2017. Thus, Cr(III) can be used as the main source of $\mathrm{Cr}$ ions, because it is considered 500 to 1000 times less toxic than hexavalent chromium [1-3]. Lately ever more exacting environmental requirements are imposed upon deposition of chromium coatings [4]. $\mathrm{CrCl}_{3}$ has become the most popular source of $\mathrm{Cr}$ (III) ions [5, 6].

$\mathrm{Cr}$ (III) electrolytes, in current use allowing deposition of functional $\mathrm{Cr}$ (III) coatings, contain various additives, most popular among them being ammonium compounds: $\mathrm{NH}_{4} \mathrm{Cl}$ [6], $\left(\mathrm{NH}_{4}\right)_{2} \mathrm{SO}_{4}$ [团 and $\mathrm{NH}_{4} \mathrm{Br}$ [8, 9]. Unfortunately,

\footnotetext{
* Corresponding author. Email: asta.cesuniene@ftmc.lt
}

they are undesirable as they are difficult to remove from spent $\mathrm{Cr}$ (III) electrolytes.

Besides, the energy consumption aspect, which is determined by the current density $(i)$ and chromium plating electrolyte temperature, is also very important. Normally, when depositing Cr coatings in the trivalent chromium plating electrolyte on iron, $i_{c}$ is in the range from 30 to $50 \mathrm{~A} \mathrm{dm}^{-2}$ [5, 10], and the working electrolyte temperature is in the range from 30 to $50^{\circ} \mathrm{C}$ [ 5 , 10 ].

Therefore, it is of great importance to search for more environment-friendly and energy efficient $\mathrm{Cr}$ (III) electrolytes.

The aim of this work was to formulate a new chromium plating electrolyte based on $\mathrm{Cr}$ (III), which would be $\mathrm{CrCl}_{2}$-free and ammonium compounds-free, and would operate at lower current densities $\left(i_{c}\right)$ and lower chromium plating electrolyte temperatures. 


\section{EXPERIMENTAL}

\section{Preparation of specimens}

Chromium coatings were electrodeposited on a mild steel (Fe-0.36 Mn, in wt.\%) substrate from the electrolytes listed below in the Table. These chromium electrolytes based on the $\mathrm{SO}^{2-}$ oxalate electrolyte were chosen because, while in use, $\mathrm{Cl}_{2}$ gas is not released at the anode [11].

All solutions were prepared using distilled water and analytical grade chemicals (manufacturer AppliChem $\mathrm{GmbH}$ ). The mild steel substrate was also treated mechanically polishing with silicon sandpaper up to \#600 grit. After that, the samples were washed with distilled water, soaked in a hot $20 \mathrm{vol} \%$ $\mathrm{HCl}$ solution, washed again with distilled water and then immediately placed in a plating bath. The electrolyte $\mathrm{pH}$ was adjusted using $\mathrm{H}_{2} \mathrm{SO}_{4}$ or $\mathrm{KOH}$. The bath of 11 volume with vertical $\mathrm{Pt}$ (with an area of $2 \times 4 \mathrm{~cm}^{2}$ ) anodes and a cathode between them was maintained at constant temperature.
The cathode (substrate) and anode were disposed within the bath at a distance of $25 \mathrm{~mm}$. Chromium deposits were obtained on both sides of the specimen (one side area was $1 \mathrm{~cm}^{2}$ ). The cathode/anode ratio was 1:4. Chromium electroplating was performed without separation of the anodic and cathodic compartments. The deposition thickness was $6 \mu \mathrm{m}$.

In pursuit of high environmental standards we modified the $\mathrm{Cr}(\mathrm{III})$ sulfate-oxalate electrolyte [10], diminished the coating deposition current density from 45 to $40 \mathrm{~A} \mathrm{dm}^{-2}$ and the working electrolyte temperature from 50 to $20^{\circ} \mathrm{C}$ (room temperature) and added heterocyclic compound 5- nitro-2- furaldehyde semicarbazone, 97\% solid produced by a Sigma-Aldrich. This compound was designed as HCC additive (Table).

For comparison purposes, $\mathrm{Cr}$ coatings were deposited from both the modified $\mathrm{Cr}$ electrolyte free from the HCC additive and that containing the HCC additive.

Table. Codes and compositions of $\mathrm{Cr}$ baths used for the electrodeposition of $\mathrm{Cr}$ (III) coatings

\begin{tabular}{|c|c|c|}
\hline Codes & Composition of $\mathrm{Cr}$ (III) bath:gl ${ }^{-1}$ & Deposition conditions \\
\hline OXL & $\begin{array}{c}\mathrm{Cr}_{2}\left(\mathrm{SO}_{4}\right)_{3} 6 \mathrm{H}_{2} \mathrm{O} 150 \\
\mathrm{Na}_{2} \mathrm{C}_{2} \mathrm{O}_{4} 35 \\
\mathrm{H}_{3} \mathrm{BO}_{3} 30 \\
\mathrm{Na}_{2} \mathrm{SO}_{4} 60 \\
\mathrm{Al}_{2}\left(\mathrm{SO}_{4}\right)_{3} 12 \mathrm{H}_{2} \mathrm{O} 100 \\
\mathrm{NaF} 15\end{array}$ & $\begin{array}{c}i_{c}=45 \mathrm{~A} \mathrm{dm}^{-2} \\
t=50^{\circ} \mathrm{C} \\
t=20 \mathrm{~min} \\
\text { non-stirring } \\
\mathrm{pH} 1.6\end{array}$ \\
\hline OX1 & $\begin{array}{c}\mathrm{Cr}_{2}\left(\mathrm{SO}_{4}\right)_{3} 6 \mathrm{H}_{2} \mathrm{O} 150 \\
\mathrm{Na}_{2} \mathrm{C}_{2} \mathrm{O}_{4} 35 \\
\mathrm{H}_{3} \mathrm{BO}_{3} 30 \\
\mathrm{Na}_{2} \mathrm{SO}_{4} 60 \\
\mathrm{Al}_{2}\left(\mathrm{SO}_{4}\right)_{3} 12 \mathrm{H}_{2} \mathrm{O} 100 \\
\mathrm{NaF} 15\end{array}$ & $\begin{array}{c}i_{c}=40 \mathrm{~A} \mathrm{dm}^{-2} \\
t=20^{\circ} \mathrm{C} \\
t=20 \mathrm{~min} \\
\text { Magnetic stirring }(350 \mathrm{rpm}) \\
\mathrm{pH} 1.6\end{array}$ \\
\hline OX2 & $\mathrm{OX} 1+20 \mathrm{mgl}^{-1}$ additive $\mathrm{HCC}$ & $\begin{array}{c}i_{c}=40 \mathrm{~A} \mathrm{dm}^{-2} \\
t=20^{\circ} \mathrm{C} \\
t=20 \mathrm{~min} \\
\text { Magnetic stirring }(350 \mathrm{rpm}) \\
\mathrm{pH} 1.6\end{array}$ \\
\hline OX3 & $\mathrm{OX} 1+40 \mathrm{mgl}^{-1}$ additive HCC & $\begin{array}{c}i_{c}=40 \mathrm{~A} \mathrm{dm}^{-2} \\
t=20^{\circ} \mathrm{C} \\
t=20 \mathrm{~min} \\
\text { Magnetic stirring }(350 \mathrm{rpm}) \\
\mathrm{pH} 1.6\end{array}$ \\
\hline OX4 & $\mathrm{OX} 1+60 \mathrm{mgl}^{-1}$ additive HCC & $\begin{array}{c}i_{c}=40 \mathrm{~A} \mathrm{dm}^{-2} \\
t=20^{\circ} \mathrm{C} \\
t=20 \mathrm{~min} \\
\text { Magnetic stirring }(350 \mathrm{rpm}) \\
\mathrm{pH} 1.6\end{array}$ \\
\hline
\end{tabular}




\section{Characterizations}

A Helios NanoLab 650 DualBeam workstation (FEI) was used for chromium coatings surface (SEM). Measurements of deposit thickness were done by using the weight and cross-section methods. The samples were weighed before and after the electrodeposition. Several specimens were analysed by producing localised cross-sections by focused Ga ion beaming with a Helios NanoLab 650. Before the formation of cross-sections on the specimens a protective platinum $(\mathrm{Pt})$ overcoat $\sim 1 \mu \mathrm{m}$ thick was deposited by electron and ion beams. Such a thick Pt overcoat layer helps avoid the Ga ion damage to the edge regions of the studied coating. Then the specimen was placed under the $\mathrm{Ga}$ ion beam exposure perpendicularly to the surface until the necessary depth was reached. SEM images of the cross-section were studied at $3 \mathrm{kV}$ accelerating voltage and $6.3 \mathrm{pA}$ current.

The measurements of deposit thickness were done by using the cross-section method.

XRD patterns of the films were measured using an X-ray diffractometer SmartLab (Rigaku) equipped with a $9 \mathrm{~kW}$ rotating $\mathrm{Cu}$ anode $\mathrm{X}$-ray tube. The grazing incidence (GIXRD) method was used in a $2 \theta$ range of $15-80^{\circ}$. The angle between the parallel beam of X-rays and the specimen surface (angle) was adjusted to $0.5^{\circ}$. Phase identification was performed using the software package PDXL (Rigaku) and ICDD powder diffraction data-base PDF-4+ (2016 release).

The crystallite size was calculated using the graphical Halder-Wagner method implemented in the PDXL software package (Rigaku). The approach is based on the graphical representation of linear relationship $(\beta / \tan \theta)^{2}$ vs $\beta /(\tan \theta$ $\sin \theta)$ plot $(\beta$ is XRD peak physical broadening, $\theta$ is diffraction angle).

The microhardness tests were performed on the surface of the coatings using a PTM-3 (Russia) set-up at a load of $50 \mathrm{~g}$. The values of $\mathrm{HV}$ are the average of five indentations.

Dry sliding ball-on-plate wear tests on the coated samples were carried out in the laboratory atmosphere with a relative humidity of $30-40 \%$ at room temperature. For tribological measurements a CSM Tribometer (Anton Paar, Switzerland) was used. The ball (100Cr6 steel) of $6 \mathrm{~mm}$ in diameter was fixed stationary. The $\mathrm{Cr}$ specimen was mounted on a pre-installed tribometer module, which maintained a linear reciprocal motion with an amplitude of $4 \mathrm{~mm}$, speed of $2 \mathrm{~cm} / \mathrm{s}$, load of $2 \mathrm{~N}$. It has been known [12] that amorphous $\mathrm{Cr}$ coatings are not suitable for high loadings, therefore we chose $2 \mathrm{~N}$ loadings for friction tests. For plotting the graphs, each data point of the friction coefficient was obtained by taking an arithmetical average of the modular values from the central $80 \%$ segment of the linear path. A contact profilometer Surftest SJ-210 was used to determine wear profiles of $\mathrm{Cr}$ coatings. As the contact needle was scanning the surfaces horizontally, it transferred the data obtained into the Image Plus software for visualization. Wear profiles were measured after friction coefficient recording, the cross-section area of wear tracks was calculated from at least 3 measurements on different wear track locations within the same specimen. Specific wear rates $\left(\mathrm{mm}^{3} / \mathrm{Nm}\right)$ were calculated using the following equation: $K=(S l) /(F d)$, where $S$ is the average cross-section area of wear track, in $\mathrm{mm}^{2} ; l$ is the length of wear track, in $\mathrm{mm} ; F$ is the load applied, in $N ; d$ is the sliding distance, in $m$. The most representative wear tracks were selected for the comparison between the samples in profilometry graphs.

\section{RESULTS AND DISCUSSION}

\section{Morphology and structure analysis}

The SEM micrographs and cross-sectional images from the surface of (OXL and OX1, OX2, OX3, OX4) $\mathrm{Cr}$ coatings are presented in Fig. 1. It can be seen that all the deposits consist of nodules. However, the nodular size depends on the temperature of chromium plating electrolyte, current density and additive concentration. A decline in the chromium plating electrolyte temperature and $i_{c}$ leads to an increased nodular size (Fig. 1 b). Addition of $20 \mathrm{mgl}^{-1}$ of the HCC additive to the OX1 electrolyte decreases the nodular size (Fig. 1 1 c). An increase in the concentration of the HCC additive up to $40 \mathrm{mgl}^{-1}$ (Fig. 1 $1 \mathrm{~d}$ ) leads to a decreased nodular size compared with the data presented in Fig. 1 c. A further increase in the HCC additive concentration up to $60 \mathrm{mgl}^{-1}$ (Fig. 1e) does not lead to any change in the nodular size compared with the data in Fig. 1 d.

In all cases (Fig. 1 a-e), we observed a small number of microcracks in the $\mathrm{Cr}$ coatings. Pores 


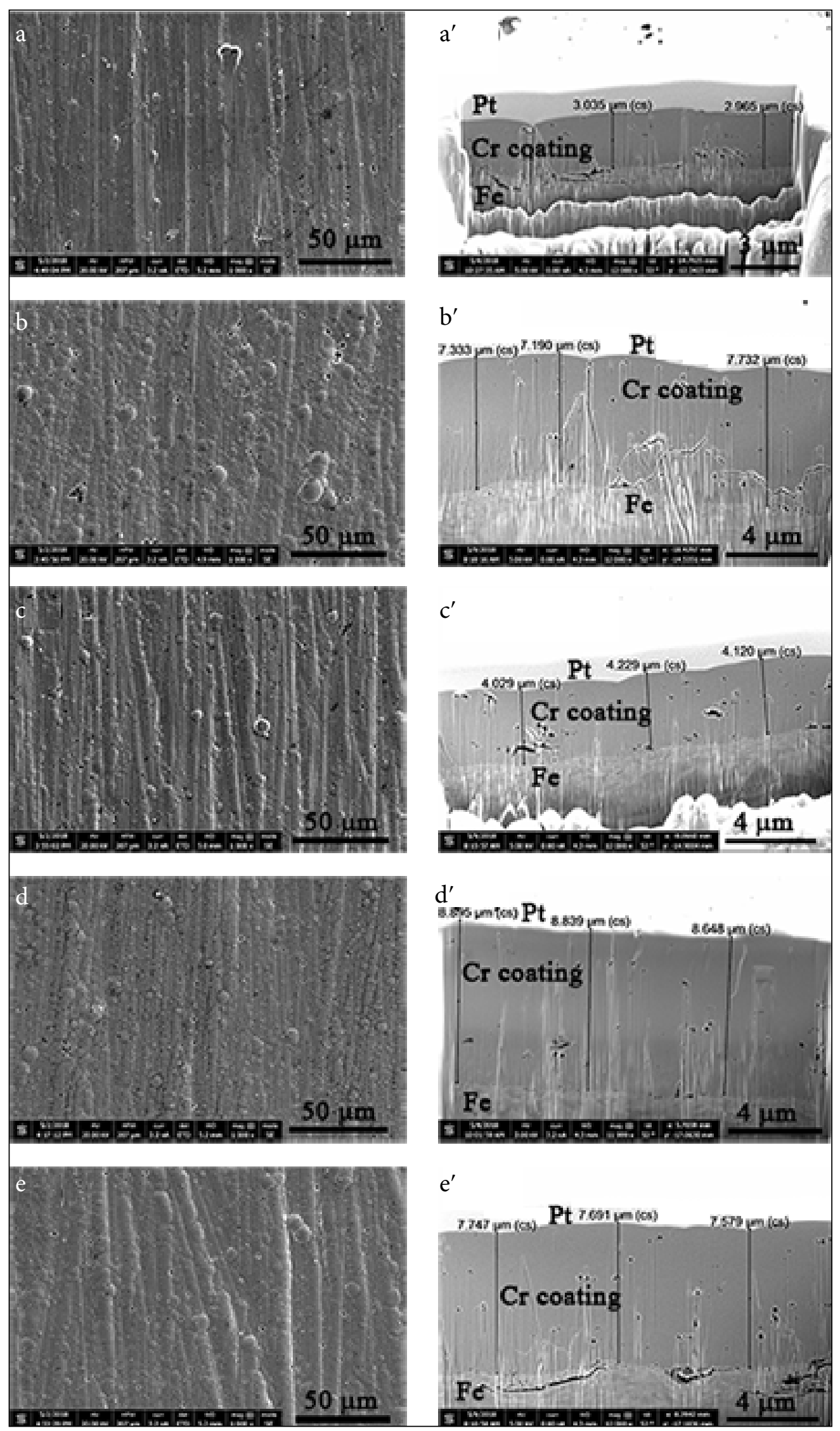

Fig. 1. SEM micrographs of the surface morphologies and the cross-sectional images for as-plated $\mathrm{Cr}$ coatings electrodeposited from the OXL and OX1 $\left(\mathrm{HCC}=0 \mathrm{mgl}^{-1}\right), 0 \times 2\left(\mathrm{HCC}=20 \mathrm{mgl}^{-1}\right), 0 \times 3\left(\mathrm{HCC}=40 \mathrm{mgl}^{-1}\right)$ and OX4 $\left(\mathrm{HCC}=60 \mathrm{mgl}^{-1}\right)$ electrolytes 
in the form of 'exploded blisters' were also observed on all the surfaces of $\mathrm{Cr}$ coatings. The inner pores can also be found in the depth of $\mathrm{Cr}$ coatings (see cross-section in Fig. 1). It should be noted that the microcracks and pores are formed due to intensive hydrogen decomposition.

The investigation of the cross-sections of $\mathrm{Cr}$ coatings has shown that the thickness of the coatings obtained varied (Fig. 1 $\left.1 \mathrm{a}^{\prime}-\mathrm{e}^{\prime}\right)$. The $\mathrm{Cr}$ coatings obtained from the OXL (Fig. 1 la') and OX2 electrolytes had the smallest thickness (Fig. 1 1c'). Meanwhile the $\mathrm{Cr}$ coatings obtained from the OX1 (Fig. 1 1b)', OX3 (Fig. 1 d') and OX4 (Fig. 11e') electrolytes were noticeably thicker.

The cross-sections of the $\mathrm{Cr}$ coatings obtained from the OXL (Fig. 1 1a') and OX1 electrolytes (Fig. 1 b') show cracks throughout the coatings. Meanwhile the Cr coatings obtained from the OX2 (Fig. 1 $c^{\prime}$ ), OX3 (Fig. 1 d') and OX4 electrolytes (Fig. 1e') are characterised by closed cracks, which

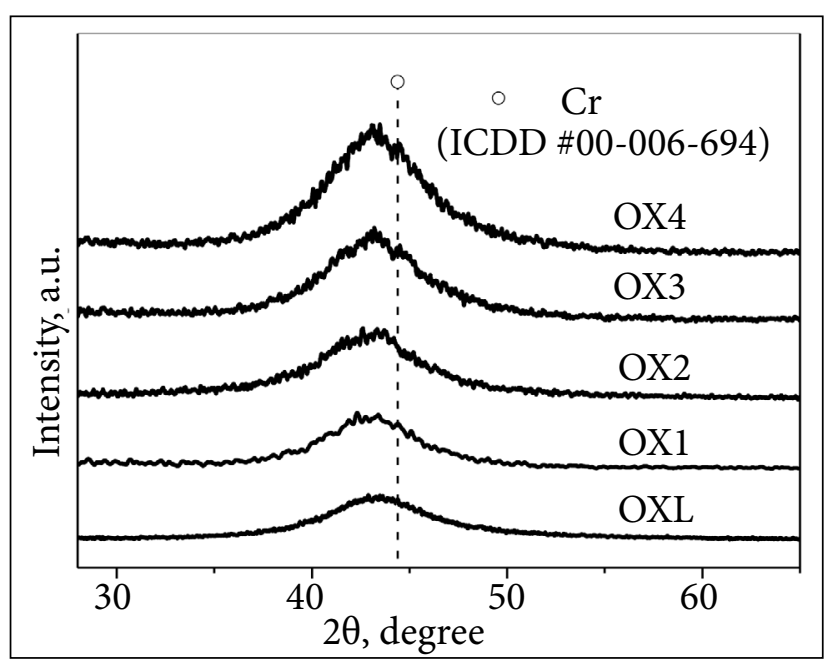

Fig. 2. XRD pattern of a mild steel substrate with the $\mathrm{Cr}$ coatings deposited from the $0 \mathrm{XL}\left(i_{c}=45 \mathrm{~A} \mathrm{dm}^{-2}, t=50^{\circ} \mathrm{C}\right), 0 \times 1\left(i_{c}=40 \mathrm{Adm}^{-2}\right.$, $\left.t=20^{\circ} \mathrm{C}, \mathrm{HCC}=0 \mathrm{mgl}^{-1}\right), 0 \times 2\left(i_{c}=40 \mathrm{Adm}^{-2}, t=20^{\circ} \mathrm{C}\right.$, $\left.\mathrm{HCC}=20 \mathrm{mgl}^{-1}\right), 0 \times 3\left(i_{\mathrm{C}}=40 \mathrm{~A} \mathrm{dm}^{-2}, t=20^{\circ} \mathrm{C}, \mathrm{HCC}=40 \mathrm{mgl}^{-1}\right)$ and $0 \times 4\left(i_{c}=40 \mathrm{~A} \mathrm{dm}^{-2}, t=60^{\circ} \mathrm{C}\right)$ baths demonstrates a direct effect of the HCC additive on the formation of $\mathrm{Cr}$ coatings. In all the cases dark spots can be seen, they are nothing but preserved hydrogen bubbles.

It is worth noting that a poor interface between the $\mathrm{Fe}$ substrate and $\mathrm{Cr}$ coatings is characteristic of OXL (Fig. 1 a') and OX4 (Fig. 1 e').

The XRD spectrum (Fig. 2) recorded for the $\mathrm{Cr}$ specimens has shown that the peaks located at $2 \theta=44.39$ are very broad. It can be considered that the as-deposited coatings are amorphous. On the other hand, it has been determined that the crystallite size of all the Cr coatings was quite small (about $1.0 \mathrm{~nm}$ ). Thus, all the Cr coatings obtained may be characterised as amorphous/nanocrystallic coatings.

It is interesting how the lattice parameters of the $\mathrm{Cr}$ coatings vary depending on the concentration of the HCC additive. The results of lattice parameters are listed in Fig. 3. As can be seen, for

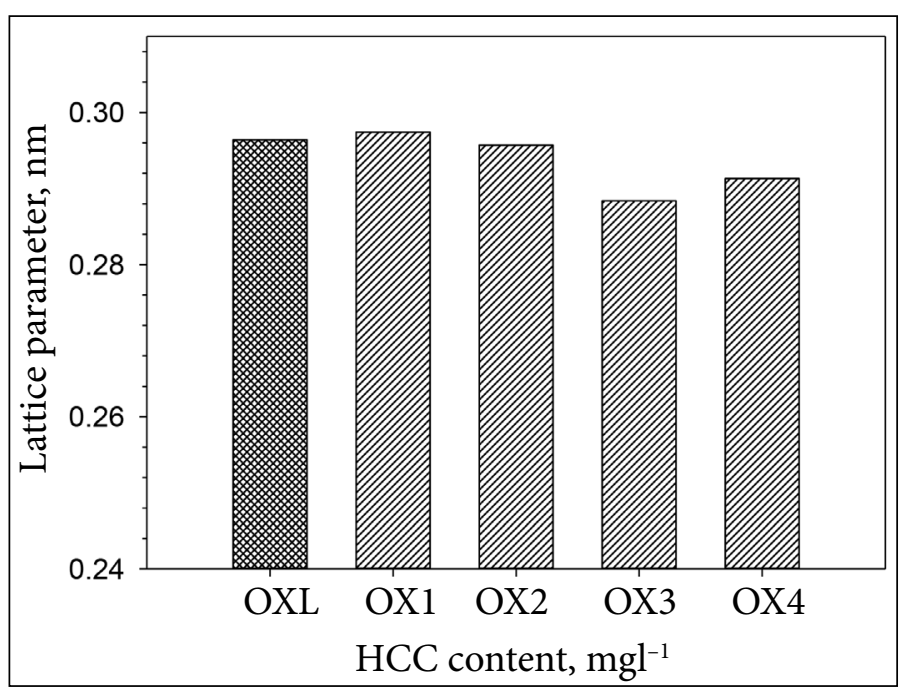

Fig. 3. Effect of the $H C C$ concentration on the lattice parameter of $\mathrm{Cr}$ coatings obtained from the OXL, OX1, OX2, OX3 and OX4 electrolytes 


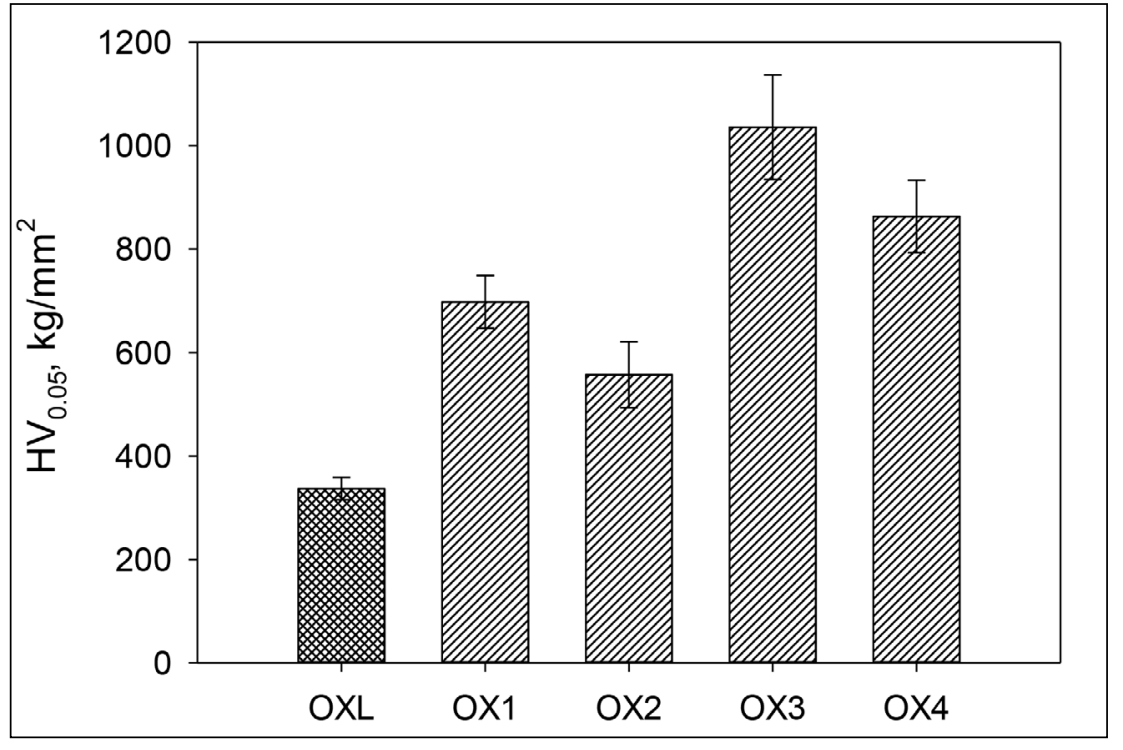

Fig. 4. Dependence of the surface microchardness (HV) of $\mathrm{Cr}$ coatings as a function of the deposition conditions and the concentration of $\mathrm{HCC}$ additive in the $\mathrm{OXL}$ and $0 \times 1\left(0 \mathrm{mgl}^{-1}\right), 0 \times 2\left(20 \mathrm{mgl}^{-1}\right), 0 \times 3$ $\left(40 \mathrm{mgl}^{-1}\right), 0 \times 4\left(60 \mathrm{mgl}^{-1}\right)$ electrolytes. The thickness of $\mathrm{Cr}$ coatings is $6.0 \pm 2.0 \mu \mathrm{m}$ the $\mathrm{Cr}$ coatings obtained from the OX1 electrolyte $\left(20^{\circ} \mathrm{C}\right.$ and $\left.40 \mathrm{~A} \mathrm{dm}^{-2} i\right)$ the lattice parameter value (0.2974) is the highest as compared to all other cases. Addition of the $20 \mathrm{mgl}^{-1} \mathrm{HCC}$ additive to the OX1 electrolyte lowers the lattice parameter of $\mathrm{Cr}$ coatings insignificantly (Fig. 3, OX2). Meanwhile, at the concentration of the HCC additive of $40 \mathrm{mgl}^{-1}$ the lattice parameter of Cr coatings becomes equal to $0.2884 \mathrm{~nm}(\mathrm{OX} 3)$. This value of the lattice parameter is identical to that of the metallic Cr (PDF 6-694). At increased up to $60 \mathrm{mgl}^{-1}$ concentrations of the HCC additive the lattice parameter also increases (Fig. 3, OX4).

\section{Microhardness}

Figure 4 illustrates the dependence of microhardness $(\mathrm{HV})$ of $\mathrm{Cr}$ coatings on the conditions of the chromium plating process and the concentration of the HCC additive in the electrolyte. A decrease in the temperature of the $\mathrm{Cr}$ plating electrolyte from $50^{\circ} \mathrm{C}$ (Fig. 4, OXL) to $20^{\circ} \mathrm{C}$ (Fig. 4, OX1) and in $i_{\mathrm{c}}$ from $45 \mathrm{~A} \mathrm{dm}^{-2}$ (Fig. 4, OXL) to $40 \mathrm{~A} \mathrm{dm}^{-2}$ (Fig. 4, OX1) leads to a twofold increase in HV. Addition of the HCC additive to the modified $\mathrm{Cr}$ electrolyte makes it possible to change the value of HV. One can see that the Cr coatings obtained in the modified $\mathrm{Cr}$ (III) electrolyte containing

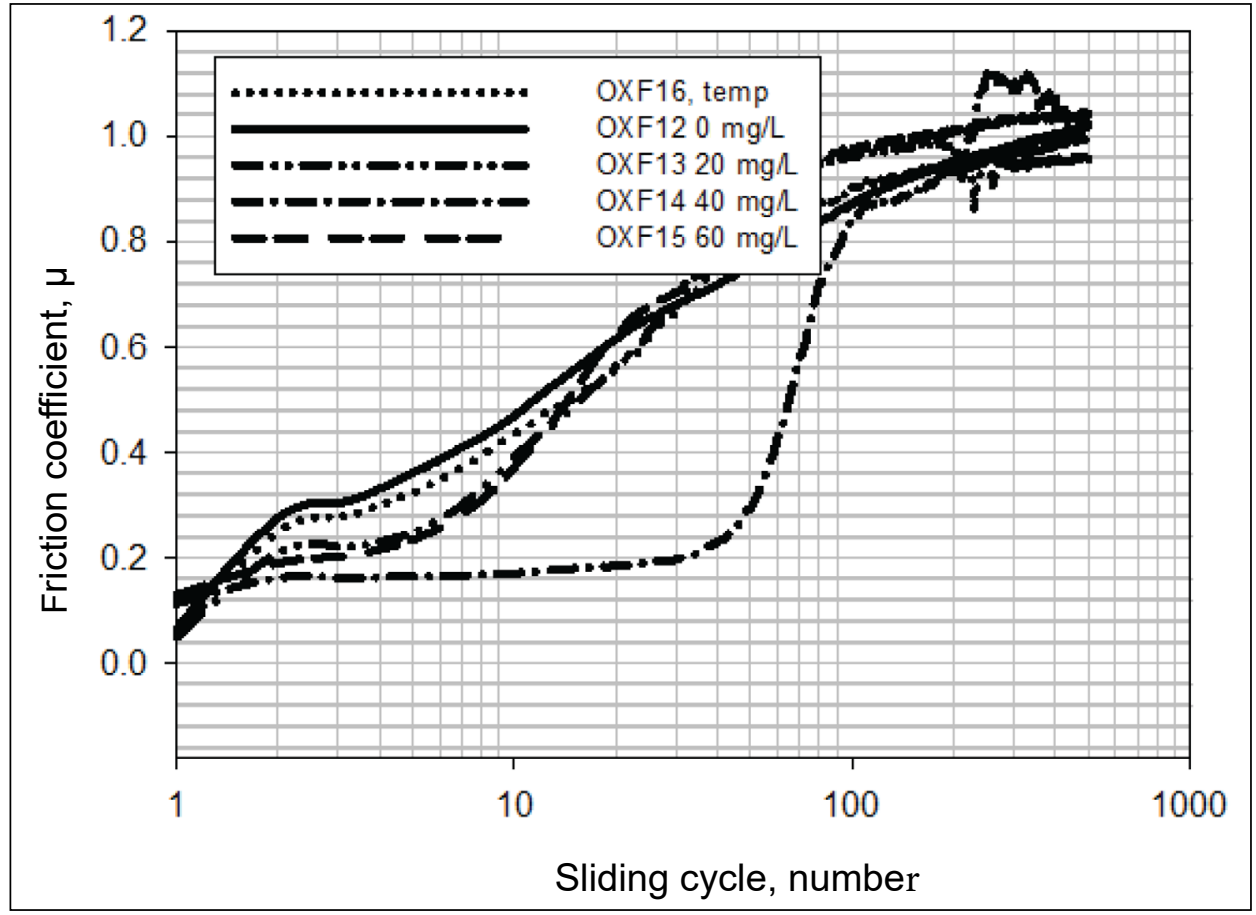

Fig. 5. The friction coefficient $(\mu)$ of $\mathrm{Cr}$ coatings as a function of the number of friction cycles for as-plated $\mathrm{Cr}$ coatings electrodeposited from OXL and OX1 ( $\left.\mathrm{HCC}=0 \mathrm{mgl}^{-1}\right)$, OX2 $\left(\mathrm{HCC}=20 \mathrm{mgl}^{-1}\right), 0 \times 3$ $\left(\mathrm{HCC}=40 \mathrm{mgl}^{-1}\right), \quad 0 \times 4$ $\left(\mathrm{HCC}=60 \mathrm{mgl}^{-1}\right)$ electrolytes 
$40 \mathrm{mgl}^{-1}$ of the HCC additive exhibited the highest $\mathrm{HV}$ value (about $1000 \mathrm{~kg} \mathrm{~mm}^{-2}$ ) (Fig. 4, OX3). It is well to bear in mind that $\mathrm{HV}$ as high as this is obtained for coatings without any subsequent heat treatment. Apparently this can be explained by nodule size. In this case they are the smallest (Fig. 1d). At increased up to $60 \mathrm{mgl}^{-1} \mathrm{HCC}$ additive concentrations HV again diminishes (Fig. 3, OX4). The obtained data on the HV of chromium coatings correlate well with the lattice parameters, that is, the values of chromium coating $\mathrm{HV}$ increase with decreasing lattice parameters. An analogous dependence was observed when studying the Cr1-xAlxN films [13].

\section{Analysis of friction coefficient and specific wear rate}

The friction coefficients of five different $\mathrm{Cr}$ coatings are shown in Fig. 5. As one can see, the friction coefficients of the Cr coatings OXL and OX1 are close to each other and they both increase very rapidly from the first friction cycles. Meanwhile OX2 and OX4 are also close to each other and have lower friction coefficients as compared to those of OXL and OX1. Only the friction coefficient of OX3, i.e. with $40 \mathrm{mgl}^{-1}$ of HCC additive, is low (about 0.2 ) and remains unchanged up to 50 cycles.

Figure 6 illustrates the dependence of the $\mathrm{Cr}$ coatings wear rate on the plating conditions and HCC additive concentration. As one can see, the improvement of $\mathrm{Cr}$ plating conditions significantly increases the specific wear rate (Fig. 6,
OXL and OX1). Meanwhile, the addition of HCC additive to the $\mathrm{Cr}$ electrolyte allows reducing the specific wear rate of $\mathrm{Cr}$ coatings. The optimal HCC additive concentration $\left(40 \mathrm{mgl}^{-1}\right)$ makes it possible to minimise the specific wear rate of $\mathrm{Cr}$ coatings (Fig. 6, OX3). At increased up to $60 \mathrm{mgl}^{-1}$ HCC additive concentrations the specific wear rate of $\mathrm{Cr}$ coatings increased again (Fig. 3, OX4). These results are in good accordance with the Archard law when the specific wear rate decreases with increasing coating microhardness [12].

\section{Worn surface morphology}

Figure 7 depicts the SEM morphologies of the worn surfaces of $\mathrm{Cr}$ coatings obtained from the OXL, OX1, OX2, OX3 and OX4 electrolytes. In Figs. 7a and $c$ the cracks propagation and delamination of $\mathrm{Cr}$ coatings is clearly seen, consequently the wear mechanism may be characterised as adhesion/ delamination. Such behaviour of the Cr coatings may also be associated with a poor interface between the Fe substrate and Cr coatings (Fig. 11a', e'). The wear mechanism of the $\mathrm{Cr}$ coatings obtained from the OX1 electrolyte can be characterised as

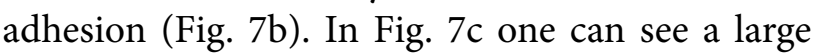
surface deformation on the worn surface without cracks. Therefore, we can characterise the wear mechanism as plastic deformation (laminar tearing). The wear mechanism of the $\mathrm{Cr}$ coatings obtained from the OX3 electrolyte, i.e. at the optimal HCC concentration, proceeds according to the wear adhesive mechanism (Fig. $7 \mathrm{~d}$ ).

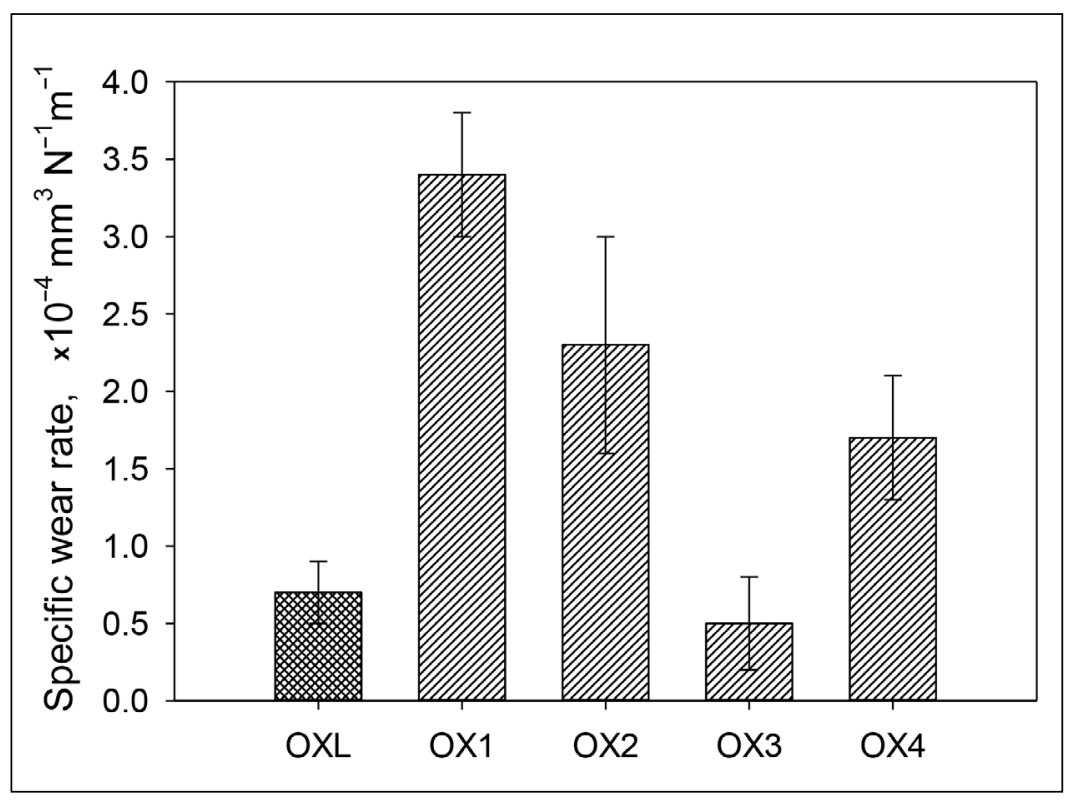

Fig. 6. Comparison of the specific wear rate of the $\mathrm{Cr}$ coatings electrodeposited from the OXL and OX1 $\left(\mathrm{HCC}=0 \mathrm{mgl}^{-1}\right), 0 \times 2\left(\mathrm{HCC}=20 \mathrm{mgl}^{-1}\right)$, OX3 $\left(\mathrm{HCC}=40 \mathrm{mgl}^{-1}\right), 0 \times 4\left(\mathrm{HCC}=60 \mathrm{mgl}^{-1}\right)$ electrolytes 

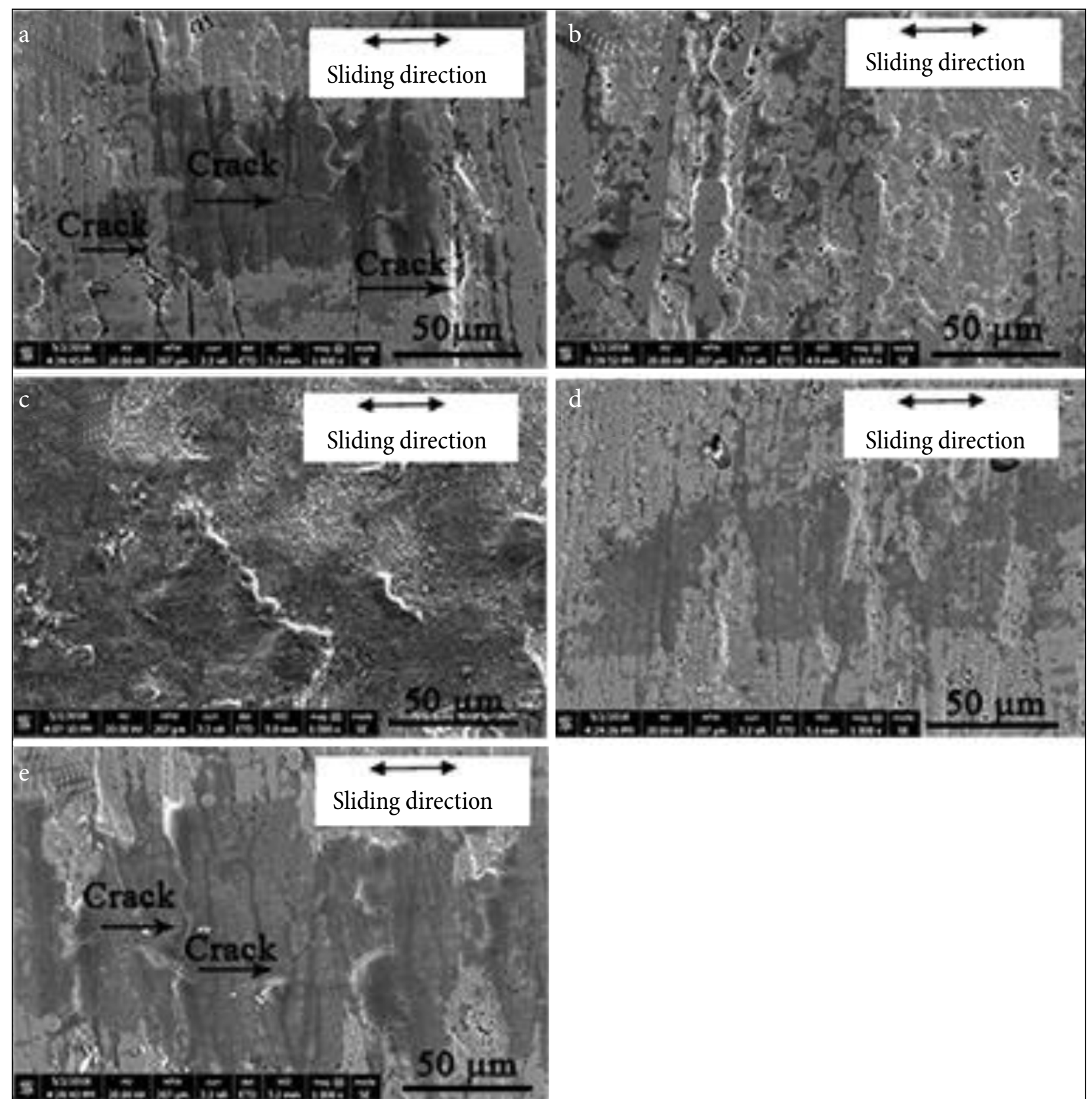

Fig. 7. SEM images of the worn surface of the $\mathrm{Cr}$ coatings electrodeposited from $0 X \mathrm{~L}$ and $0 \times 1\left(0 \mathrm{mgl}^{-1}\right), 0 \times 2\left(\mathrm{HCC}=20 \mathrm{mgl}^{-1}\right), 0 X 3$ $\left(\mathrm{HCC}=40 \mathrm{mgl}^{-1}\right), 0 X 4\left(\mathrm{HCC}=60 \mathrm{mgl}^{-1}\right)$ electrolytes

It is obvious that there is no way to deposit high quality chromium coatings with the properties described above in an electrolyte free from the HCC additive, even all other conditions (composition of the electrolyte, temperature and current density) being the same.

\section{CONCLUSIONS}

1. The chromium plating electrolyte containing the HCC additive enables us to deposit Cr coatings at low $\left(20^{\circ} \mathrm{C}\right)$ temperature and low current densities.
2. All the $\mathrm{Cr}$ coatings exhibited nodular morphology. The $\mathrm{Cr}$ coatings obtained from the electrolyte with the optimum concentration of $40 \mathrm{mgl}^{-1}$ of the HCC additive possessed the smallest nodular size.

3. Employing the XRD method it has been determined that all the $\mathrm{Cr}$ coatings are amorphous/ crystalline.

4. The $\mathrm{Cr}$ coatings obtained from the $\mathrm{Cr}$ electrolyte with the optimum concentration of $40 \mathrm{mgl}^{-1}$ of the HCC additive exhibited the highest surface microhardness of about $1000 \mathrm{~kg} \mathrm{~mm}^{-2}$. 
5. The Cr coatings obtained from the $\mathrm{Cr}$ electrolyte with the optimum concentration of $40 \mathrm{mgl}^{-1}$ of the HCC additive possessed the lowest friction coefficient of about 0.2 .

6. At the HCC additive concentrations of 20,40 and $60 \mathrm{mgl}^{-1}$ in the Cr electrolyte, the wear mechanisms were as follows: plastic deformation, adhesion or adhesion/delamination, respectively.

Received 13 February 2019 Accepted 26 February 2019

\section{References}

1. L. Li, G. P. Swain, A. Howell, D. Woodbury, G. M. Swain, J. Electrochem. Soc., 158, C274 (2011).

2. L. Li, K. P. Doran, G. M. Swain, J. Electrochem. Soc., 160, C396 (2013).

3. L. Li, A. L. Desouza, G. M. Swain, J. Electrochem. Soc., 161, C246 (2014).

4. Federal Register, Vol. 77, No. 182 https://www. gpo.gov/fdsys/pkg/FR-2012-09-19/pdf/201220642.pdf].

5. Ch. A. Huang, Y. W. Liu, Ch. Yu, Ch.-Ch. Yang, Surf. Coat. Technol., 205, 3461 (2011).

6. A. Liang, L. Ni, Q. Liu, J. Zhang, Surf. Coat. Technol., 218, 23 (2013).

7. V. Protsenko, V. Gordiienko, T. Butyrina, E. Vasileva, F. Danilov, Turk. J. Chem., 38, 50 (2014).

8. S. C. Kwon, M. Kim, S. U. Park, et al., Surf. Coat. Technol., 183, 151 (2004).
9. Z. Zeng, J. Zhang, Surf. Coat. Technol., 202, 2725 (2008).

10. A. A. Edigaryan, V. A. Safonov, E. N. Lubnin, L. N. Vykhodtseva, G. E. Chusova, Yu. M. Polukarov, Electrochim. Acta, 47, 2775 (2002).

11. V. S. Protsenko, F. I. Danilov, Clean Techn. Environ. Policy, 16, 1201 (2014).

12. Z. Zeng, L. Wang, L. Chen, J. Zhang, Surf. Coat. Technol., 201, 2282 (2006).

13. M. Kawate, A. Kimura, T. Suzuki, J. Vac. Sci. Technol., A, 20, 569 (2002).

Gedvidas Bikulčius, Asta Češūnienė, Tadas Matijošius, Aušra Selskienė, Vidas Pakštas

\section{CR DANGŲ, GAUTŲ PAGERINTAME CR(III) ELEKTROLITE, SAVYBIU TYRIMAS}

Santrauka

Tirtos chromo dangų, gautų $\mathrm{Cr}$ (III) sulfatinejje vonioje su heterocikliniu junginiu (HCJ) ant minkšto plieno, mechaninès ir tribologinès savybès. Chromavimo elektrolitas su HCC priedu leidžia gauti Cr dangas žemoje $\left(20^{\circ} \mathrm{C}\right)$ temperatūroje prie žemų srovès tankių. Pastebèta, kad pridejjus į Cr(III) sulfatinę vonią mažas koncentracijas HCJ (nuo $20 \mathrm{mgl}^{-1}$ iki $60 \mathrm{mgl}^{-1}$ ) priedo, dangu savybès kinta. Nustatyta, kad optimali HCJ $\left(40 \mathrm{mgl}^{-1}\right)$ koncentracija leidžia gauti kietas $\mathrm{Cr}$ dangas $\left(\mathrm{HV} 0.05=1036 \mathrm{~kg} \mathrm{~mm}^{-2}\right)$ jų nekaitinant. Sausos trinties bandymai parodè, kad Cr pasižymi žemu trinties koeficientu ir žema dilimo norma. Cr(III) vonia su HCJ priedu, palyginti su klasikiniu Cr(III) procesu, yra ekologiškesnè ir reikalauja mažiau energijos. 